\title{
PRIMARY DYSMENORRHEA RISK BASED ON CHARACTERISTICS, DIETARY HABITS, AND TYPES OF EXERCISE
}

\author{
Asti Dewi Rahayu Fitrianingsih*, Ayu Mutiara Santanu \\ Faculty of Sports and Health Education, Universitas Pendidikan Indonesia, Jl. Dr. Setiabudi Bandung, \\ 40154, Indonesia
}

\begin{abstract}
The young woman's frequent complaint related to reproduction health is dysmenorrhea. The incidence of primary dysmenorrhea is affected by various factors. The purpose of the study was to examine the factors affecting primary dysmenorrhea, including characteristics, dietary habits, and types of exercise. The research was quantitative research using correlational analytic method with a cross-sectional approach. The samples of the study were 97 female college students of The Faculty of Sports and Health Education, Universitas Pendidikan Indonesia. The sampling technique used was the Consecutive Sampling technique. There were two variables related to the primary dysmenorrhea, including breakfast habits (OR: 0,007; p:0,004) and positive family history (OR: 1,14; p:0,001). Meanwhile, BMI (OR: 3,1; p:0,317), fiber consumption habits (OR: 0,129; p:0,076), types of snack (OR: 0,14; p:0,083), types of exercise (OR: 27,4; p:0,074), and the interaction of fiber consumption and breakfast habit (OR: 0,129; p:0,076) were confounding variables. The breakfast habit was the most affecting variable (B:5,35). By considering the negative impacts of dysmenorrhea, the female college student should start taking breakfast every day, especially for those who have family members with primary dysmenorrhea history.
\end{abstract}

Keywords: primary dysmenorrhea, reproductive health, young women

\begin{abstract}
ABSTRAK
Dismenore adalah keluhan terkait kesehatan reproduksi yang sering dikeluhkan oleh remaja puteri. Dismenore primer dipengaruhi oleh berbagai faktor. Tujuan dari penelitian ini adalah untuk mengetahui faktor-faktor yang mempengaruhi dismenore primer yang meliputi karakteristik, kebiasaan makan, dan jenis olah raga. Penelitian ini merupakan penelitian kuantitatif dengan metode analitik korelasional dengan pendekatan cross-sectional. Sampel penelitian adalah 97 mahasiswi Fakultas Pendidikan Olahraga dan Kesehatan Universitas Pendidikan Indonesia. Teknik pengambilan sampel yang digunakan adalah teknik Consecutive Sampling. Ada dua variabel yang berhubungan dengan dismenore primer, yaitu kebiasaan sarapan (OR: 0,007; p: 0,004) dan riwayat anggota keluarga yang mengalami dismenore (OR: 1,14; p: 0,001). Sedangkan IMT (OR: 3,1; p: 0,317), kebiasaan konsumsi serat (OR: 0,129; p: 0,076), jenis makanan ringan (OR: 0,$14 ; p: 0,083$ ), jenis olahraga (OR: 27,4; $p: 0,074$ ), dan interaksi konsumsi serat dan kebiasaan sarapan pagi (OR: 0,129; p: 0,076) merupakan variabel perancu. Kebiasaan sarapan merupakan variabel yang paling berpengaruh (B: 5,35). Dengan mempertimbangkan dampak negatif dismenore, sebaiknya mahasiswi mulai sarapan setiap hari, terutama bagi yang mempunyai anggota keluarga dengan riwayat dismenore primer.
\end{abstract}

Kata kunci: dismenore primer, kesehatan reproduksi, remaja puteri

Correspondece Address: Asti Dewi Rahayu Fitrianingsih, Faculty of Sports and Health Education, Universitas Pendidikan Indonesia, Jl.Dr. Setiabudi Bandung, 40154, Indonesi,E-mail: rahayufitria@upi.edu 


\section{Introduction}

Dysmenorrhea is a gynaecology complaint frequently experienced by women. The symptoms of dysmenorrhea include feeling unwell, tired, nausea and vomiting, diarrhea, low back pain, headache, anxiety, restless, impatience, balance loss, and, sometimes, accompanied by vertigo. ${ }^{1,2}$ The prevalence of dysmenorrhea is fairly high worldwide. The average incidence of dysmenorrhea in young women is about $16,8-81 \%$. In European countries, on average, dysmenorrhea is experienced by $45-97 \%$ of women. The lowest prevalence is in Bulgaria $(8,8 \%)$ and the highest is in Finland (94\%). The highest dysmenorrhea prevalence is found in female adolescents, around 20-90\%. ${ }^{3}$ In Indonesia, dysmenorrhea also frequently occurs in adolescents with $43 \%$ to $93 \%$ of prevalence, where $74-80 \%$ of adolescents experience a mild dysmenorrhea. ${ }^{4}$

Dysmenorrhea is classified into primary and secondary dysmenorrhea. Primary dysmenorrhea is pain during the menstrual period that occurred without gynecology rudiments, mostly started from 6-12 months after menarche and could continue until menopause. ${ }^{5,6}$ Dysmenorrhea is mostly experienced by young women aged 18 - 25 years and decreases as they get older. ${ }^{7}$ The dysmenorrhea prevalence that occurred in college students includes a severe pain experienced by $34,2 \%$ of college students; a moderate pain experienced by $36,6 \%$ of college students; and mild pain experienced by $29,2 \%$ of college students. ${ }^{8}$

There are factors that influence the incidence of primary dysmenorrhea, such as characteristics of young women (Age, BMI, History of Dysmenorrhea in Family), diet, and physical activity carried out by young women. ${ }^{1,7,9}$ World Health Organization (WHO) states that, globally, women $(84 \%)$ have a higher percentage of the lack of physical activity than men (78\%). Women have a high percentage due to the lack of physical activity in their spare time and a sedentary lifestyle, both at home and at work. Indonesian women have a sedentary lifestyle or low physical activity intensity. ${ }^{10}$ The lack of physical activity will decrease the oxygen distribution in the systemic circulation that increases the individual perception on pain, including dysmenorrhea. Physical activity can be carried out through exercises. The type of exercise is divided into two types, including dominant aerobic exercise and dominant anaerobic exercise. Aerobic gymnastics can remedy of primary dysmenorrhea. Therefore, aerobic exercise can be used to medicate of primary dysmenorrhea. ${ }^{11}$ It is different from the research conducted by Moradpour that found that there was no significant examined change of the 8-week aerobic exercise on dysmenorrhea. ${ }^{12}$

The Covid-19 pandemic has not only changed physical activity but also changed people's dietary habits. ${ }^{13}$ Dietary habits that have changed a lot, especially among young girls, include breakfast habits, types of snacks consumed, fiber intake, and habits of consuming fast food. Diet will affect the incidence of dysmenorrhea. ${ }^{14,15}$ Efrizal Wiwin's research found that people during 
the Covid-19 pandemic changed their food consumption habits a lot because of the obligation to maintain a healthy body to consume ready-to-eat food. ${ }^{16}$ The level of consumption of ready-to-eat food has decreased because, during the Covid-19 pandemic, people had to do Work From Home (WFH) so that young women have time to serve their meals at home. It, of course, will have an impact on their health. Consuming ready-to-eat-food is associated with the incidence of primary dysmenorrhea because most ready-to-eat foods contain high fat and sugar. High fat and sugar will increase the levels of the prostaglandin hormone, which causes the uterus to contract, thus it causes pain during menstruation. ${ }^{17}$

Changes in dietary habits also affect breakfast habits. Only $65.6 \%$ of adolescents had the habit of having breakfast during the COVID-19 pandemic. ${ }^{14}$ There was a relationship between breakfast habits and the incidence of primary dysmenorrhea. ${ }^{18}$ Besides having the habit of skipping breakfast, female adolescents have a habit of snacking. The types of snacks that are usually preferred are sweet snacks and savory snacks. The risk of dysmenorrhea is increased in women who consume a lot of sugar. Inconsistently, Tavallaee M, Joffres MR, Corber SJ, Bayanzadeh M, Rad MM. and Mohamadirizi and Kordi found no association between sugar intake and dysmenorrhea. ${ }^{19}$ One study reported a higher prevalence of dysmenorrhea in women who consumed snacks with excess salt intake compared with those who had a minimal salt intake. ${ }^{20}$ Two other studies reported that there was no significant association between high salt intake and dysmenorrhea. ${ }^{21,22}$

Another dietary habit in young women is consuming ready-to-eat foods. Ready-to-eat food and the types of snacks are high in calories and low in micronutrients, such as vitamins, minerals, amino acids, and fiber. Arianto said that, on average, students consume instant noodles 3 times a day. ${ }^{23}$ Ansari also said that young women who live far from their parents have low levels of fruit and vegetable consumption. ${ }^{24} \mathrm{~A}$ study of the relationship between fiber consumption and dysmenorrhea shows that people who often consume fiber can reduce their pain during menstruation. ${ }^{25}$

In addition, the Covid-19 pandemic causes anxiety and stress in young women. The anxiety can result in disorders of appetite and food consumption. ${ }^{26,27}$ Swaffield B Jim \& Guo Qi said that the anxiety and stress in young women would affect their appetite that will certainly impact their nutritional status. ${ }^{28}$ It is different from the results of research conducted by Kurniawati Widi \& Luh Made K.S who argue that anxiety and stress will increase the appetite. ${ }^{27}$ Malnutrition in adolescent would affect of the reproductive organ function. A deficiency of nutrition, such as vitamin A, vitamin E, vitamin C, Magnesium (Mg), Iron (Fe), Zinc ( $\mathrm{Zn}$ ), manganese (Mn), and fatty-acids, will aggravate of dysmenorrhea. ${ }^{11}$ An overweight young woman, hyperplasia of the veins of the 
reproductive organs causes primary dysmenorrhea. Young women exceeding normal body mass index have high levels of prostaglandins that can lead to primary dysmenorrhea. ${ }^{29}$

Primary dysmenorrhea in young women can interfere with their daily activities, which has impacts on both their individual and also community due to frequent absences from classes and jobs; it is also the cause of the high sedative use among adolescents. ${ }^{8}$ Primary dysmenorrhea can also be the reason why the young women have more days off than their achievements, so that menstrual disorders need a good evaluation because, if it is not immediately treated, it will affect the quality of life and daily activity. ${ }^{30}$ This research was held on college students in the Faculty of Sports and Health Education (FPOK UPI). The majority of them were regional athletes and national athletes. The female athlete who has primary dysmenorrhea would be the most affected during the training activity and competition. For that reason, the researchers were interested in conducting a study on primary dysmenorrhea risk analysis based on dietary habits and types of exercise of the students, because primary dysmenorrhea needs to be evaluated properly. If it is not handled immediately, it will affect the quality and daily activities of female adolescents. The purpose of the study was to examine the factors affecting primary dysmenorrhea, including characteristics, dietary habits, and types of exercise.

\section{Method}

The research is quantitative research employing an analytical correlational method through a cross-sectional approach. The subjects of the research were college students in the 2017, 2018, and 2019 class years registered as active students of The Faculty of Sport and Health Education, Universitas Pendidikan Indonesia (UPI), who fulfilled the inclusion criteria. The inclusion criteria included registered as active students of Faculty of Sport and Health Education Universitas Pendidikan Indonesia (FPOK UPI) in 2020, unmarried, and did not have a secondary dysmenorrhea history. Students from the FPOK UPI were selected as the study population because most of them were athletes at the regional and national levels. Primary dysmenorrhea on athletes will certainly affect their training activity, their performance while competing, and also the achievement obtained. The researcher used the Taro Yamane and Slovin formulas in Riduan and Akdon with 772 populations and $10 \%$ precision. ${ }^{31}$ Therefore, the minimum number of the sample was 88 samples. Then, $10 \%$ of the number was added, thus the total of the samples were 97 respondents.

Due to the Covid-19 pandemic, including in Indonesia, and the escalation of the number of infected patients, the researchers limited or decreased the direct contact with the respondents during the data collection process, so that the data collection process was conducted at FPOK UPI by administering an interview through a questionnaire. Before the questionnaire was distributed to the respondents, the validity and reliability of the questionnaire were tested. 
The questionnaire was then distributed to the respondents through the Google Form link. The variables measured in this study were the incidence of primary dysmenorrhea as the dependent variable and the independent variables included age, breakfast habits, types of snack, fiber intake, ready-to-eat food, types of exercise, and history of dysmenorrhea in family. A young woman is said to get primary dysmenorrhea when she gets one or more of the signs and symptoms of primary dysmenorrhea, such as cramping pain in lower abdomen, feeling unwell, tired, nausea and vomiting, diarrhea, low back pain, headache, restlessness, impatience, and vertigo. The pain starts 1 to 3 days before menstruation, peaks in 24 hours after the start of menstruation, and subsides within 2 to 3 days. ${ }^{1,2}$. BMI measurement is done independently to prevent the spread of the covid-19 virus and most students live outside the city, it is not possible for them to come to the faculty laboratory for measurements, so that BMI measurements are carried out by family members or friends, then the results of these measurements are photographed and then sent to the researcher.

The sampling technique used was Consecutive Sampling. The researchers needed 5 weeks to collect the data. The collected data were then processed (editing, coding, entry, cleaning). This study used multivariate logistic regression analysis with STATA version 16 statistical software. Independent variables were stored in the form of a database program for the further analysis carried out in several stages, namely univariate, bivariate, and multivariate.

Univariate analysis was aimed to provide an overview of the research variables, while bivariate analysis was aimed to select independent variables that can be stored into the next test stage, namely multivariate logistic regression analysis. If the results of the bivariate analysis show $p$-value $\leq 0.25$, the independent variable can be included in the multivariate model analysis. Conversely, if the results of the bivariate analysis show a p-value $>0.25$, these variables must be excluded from the multivariate modeling, unless the variable is important for the researcher and theoretically affects the related variables. The analysis process was continued by using Multivariate Logistic Regression Analysis. Multivariate analysis was carried out to see the relationship of several (more than one) independent variables with one or more dependent variables. The modeling stage were:

1. Did the complete modelling, covering the main variables, all confounding candidates, and interaction candidates.

2. Assessed the interaction between independent variables by removing the interaction variable. The interaction variables with insignificant $p$-value were removed from the model, sequentially, one by one from the largest $\mathrm{p}$-value.

3. Assessed the confounding variables by removing the confounding variables one by one starting from the larges p-value. The confounding variable is declared if after the removal the difference between the OR of the factor or the main variable between before and after the 
release of the covariate variable is more than $10 \%$. The variables that are declared confounding must remain in the model.

This research has passed the ethical clearance process conducted by the Ethical Research Committee with the number 994/UN6.KEP/EC/2020.

\section{Results}

The dependent variable of the research was the dysmenorrhea incident, while the independent variables of the study were age, Body Mass Index (BMI), breakfast habits, types of snacks, fiber consumption habits, ready-to-eat food consumption habits, and history of family dysmenorrhea.

Table 1. Description of The Affecting Dysmenorrhea Incident

\begin{tabular}{|c|c|c|}
\hline Variable & $\begin{array}{c}\text { Average } \\
(\text { min-max })\end{array}$ & $\begin{array}{c}\text { Total }(n=97) \\
\text { Percentage }(\%)\end{array}$ \\
\hline \multicolumn{3}{|l|}{ Dysmenorrhea } \\
\hline Yes & & 36,08 \\
\hline No & & 63,92 \\
\hline Age & $\begin{array}{c}18,97 \\
(17-23 \text { years old })\end{array}$ & \\
\hline \multicolumn{3}{|l|}{ BMI } \\
\hline Underweight & & 32,99 \\
\hline Normal & & 52,58 \\
\hline Overweight & & 14,43 \\
\hline \multicolumn{3}{|l|}{ Breakfast Habits } \\
\hline Rare $(<1-3 \mathrm{x} /$ week $)$ & & 35,05 \\
\hline Often ( $\geq 1 \mathrm{x} /$ day $)$ & & 64,95 \\
\hline \multicolumn{3}{|l|}{ Types of Snack } \\
\hline Savory & & 63,92 \\
\hline Sweets & & 36,08 \\
\hline \multicolumn{3}{|l|}{ Fiber Intake } \\
\hline $\operatorname{Rare}(<1-3 \mathrm{x} /$ week $)$ & & 38,14 \\
\hline Often ( $\geq 1 \mathrm{x} /$ day) & & 61,86 \\
\hline \multicolumn{3}{|l|}{ Ready-to-Eat Food } \\
\hline Often ( $\geq 1 \mathrm{x} /$ day $)$ & & 50,52 \\
\hline Rare $(<1-3 \mathrm{x} /$ week $)$ & & 49.48 \\
\hline \multicolumn{3}{|l|}{ Types of Exercise } \\
\hline Anaerobic & & 49,48 \\
\hline Aerobic & & 50,52 \\
\hline \multicolumn{3}{|c|}{ History of Dysmenorrhea in Family } \\
\hline Yes & & 32,99 \\
\hline No & & 67,01 \\
\hline
\end{tabular}

The result of the analysis shows that most of the female college students did not experience primary dysmenorrhea, the proportion was $63,92 \%$. The result of the analysis shows that the average age of the students in this research was 18,97 years. The youngest was 17 years and the oldest was 23 years. The BMI of the students was mostly normal $(52,58 \%)$. The majority of the students frequently had breakfast $(64,95 \%)$. The favorite snack-type was savory snacks $(63,92 \%)$. The students rarely consumed high-fiber food $(61,86 \%)$ and often consumed ready-to-eat food 
$(50,52 \%)$. Furthermore, most of the respondents did not have the dysmenorrhea history in their family. The analysis was continued to bivariate analysis. See Table 2.

Table 2. Bivariate Selection of Independent Variable Involved in Multivariate Analysis

\begin{tabular}{|c|c|c|c|c|c|}
\hline \multirow{2}{*}{ Variable } & \multicolumn{2}{|c|}{ Dysmenorrhea } & \multirow[t]{2}{*}{ Total } & \multirow[t]{2}{*}{ P value } & \multirow[t]{2}{*}{ OR } \\
\hline & Yes $(\%)$ & No (\%) & & & \\
\hline \multicolumn{6}{|l|}{ BMI } \\
\hline Underweight & 7,2 & 25,8 & 33,0 & 0,010 & 3,7 \\
\hline Normal & 26,8 & 25,8 & 52,6 & baseline & baseline \\
\hline Overweight & 2,1 & 12,3 & 14,4 & 0,024 & 6,2 \\
\hline \multicolumn{6}{|l|}{ Age } \\
\hline 17 & 4,1 & 5,2 & 9,3 & 0,680 & 0,9 \\
\hline 18 & 10.3 & 22,7 & 33,0 & & \\
\hline 19 & 11,3 & 20,6 & 19,5 & & \\
\hline 20 & 4,1 & 8,2 & 12,3 & & \\
\hline 21 & 3,1 & 3,1 & 6,2 & & \\
\hline 22 & 2,1 & 2,1 & 4,2 & & \\
\hline 23 & 1,0 & 2,1 & 3,1 & & \\
\hline \multicolumn{6}{|l|}{ Breakfast Habits } \\
\hline Rare & 23,7 & 11,3 & 35 & 0,001 & 0,1 \\
\hline Often & 12,4 & 52,6 & 65 & Reff & \\
\hline \multicolumn{6}{|l|}{ Types of Snack } \\
\hline Savory & 33 & 31 & 64 & 0,001 & 0,9 \\
\hline Sweets & 3,0 & 33 & 36 & $\operatorname{Reff}$ & \\
\hline \multicolumn{6}{|l|}{ Fiber Intake } \\
\hline $\operatorname{Rare}(<1-3 \mathrm{x} /$ week $)$ & 23,7 & 14,4 & 38,1 & 0,001 & 0,2 \\
\hline Often ( $\geq 1 \mathrm{x} /$ day $)$ & 12,4 & 49,5 & 61,9 & Reff & \\
\hline \multicolumn{6}{|c|}{ Ready-to-Eat $\quad$ Food } \\
\hline Consumption & & & & & \\
\hline Often & 19,6 & 31,0 & 50,5 & 0,577 & 0,8 \\
\hline $\operatorname{Rare}(<1-3 \mathrm{x} /$ week $)$ & 16,4 & 33,0 & 49,4 & Reff & \\
\hline \multicolumn{6}{|l|}{ Types of Exercise } \\
\hline Anaerobic & 24,7 & 24,7 & 49,4 & 0,006 & 0,3 \\
\hline Aerobic & 11,3 & 39,3 & 50,6 & $\operatorname{Reff}$ & \\
\hline \multicolumn{6}{|c|}{ Positive Family History } \\
\hline Yes & 27,8 & 5,2 & 33 & 0,001 & 0,2 \\
\hline No & 8,2 & 58,8 & 67 & Reff & \\
\hline
\end{tabular}

Table 2 describes that 7,2\% of respondents with underweight BMI experienced primary dysmenorrhea; $26,8 \%$ of respondents with normal BMI experienced primary dysmenorrhea; and $2,1 \%$ of the respondents with overweight BMI experienced dysmenorrhea. According to bivariate analysis, there was a relationship between BMI and the incidence of primary dysmenorrhea. BMI gained p-value $<0,25$, thus the BMI variable could be included in the multivariate model. The average of the age of the respondents was 18,97 , p-value $>0,25$, thus the age variable was excluded from the multivariate model. The number of students who frequently took breakfast and did not experience primary dysmenorrhea was $52,6 \%$. The breakfast habit variable gained $p$-value $<0,25$, thus the breakfast habit variable was included into the multivariate variable. Moreover, $33 \%$ of the respondents who liked savory snacks experienced primary dysmenorrhea. According to the 
bivariate analysis, there was a relationship between the types of snacks and the incident of primary dysmenorrhea, $p$-value $<0,25$, thus the type of snack variable could be included in the multivariate model.

There were $61,9 \%$ of female college students who often consumed dietary fiber and did not experience dysmenorrhea. By considering the bivariate analysis, there was a relationship between consuming fiber and the primary dysmenorrhea incidence. The fiber consumption habit variable gained $\mathrm{p}$ value $<0,25$, thus it was included into the multivariate model. There was $33 \%$ of female college students who had eating out habit and did not experience dysmenorrhea. By considering the bivariate analysis, there was a relationship between the eating out habit and the incidence of primary dysmenorrhea. This variable gained $\mathrm{p}$ value $<0,25$, thus it was included into the multivariate model. $39,3 \%$ of the students practicing aerobic exercise did not experience dysmenorrhea. According to the bivariate analysis, there was a relationship between the types of exercise and the primary dysmenorrhea incidence. The type of exercise variable gained $p$ value $<$ 0,25 , thus the type of exercise could be included into the multivariate model. In addition, $58,8 \%$ of respondents, who did not have dysmenorrhea history in their family, did not experience primary dysmenorrhea. The positive family history variable gained $\mathrm{p}$ value $<0,25$, thus the history of dysmenorrhea variable could be included into the multivariate model.

The result of analysis showed that the modelling variable candidates to be included into the multivariate analysis were BMI, breakfast habits, fiber consumption habits, types of snack, types of exercise, and history of primary dysmenorrhea in family. In this stage, the interaction test of the independent variables, that theoretically had interactions among variables, was administered. The result of the interaction test showed that there was an interaction between the fiber consumption habit and the breakfast habit (fiberconsumption\#breakfasthabit), then it would be included into the full model.

After collecting all variables fulfilling the requirements to be included into the Full Model, including passing the bivariate analysis test and interaction test, the control on the confounding variables was conducted. The first excluded variable was the variable gaining the highest $p$-value. It was the interaction variable fiberconsumption\#breakfasthabit. The result of analysis showed that after the fiber consumption and breakfast habit variables were excluded, the change on OR was $>10 \%$, thus the fiberconsumption\#breakfasthabit variable was included into the model. Furthermore, the next confounding variables gaining the highest $p$ value were the type of exercise and BMI. There was a change on OR $>10 \%$, thus the type of exercise variable was included into the model. The multivariate logistic regression modelling was conducted by including independent variables and interaction variables, so that the final model was obtained, which can be seen in the table 3. 
Table 3. Final Result of the Influential Factors of Dysmenorrhea Incidence

\begin{tabular}{|c|c|c|c|}
\hline Variable & B & OR & P value \\
\hline \multicolumn{4}{|l|}{ BMI } \\
\hline Underweight & 1,13 & 3,10 & 0,317 \\
\hline Normal & Reff & Reff & Reff \\
\hline Overweight & 2,44 & 11,5 & 0,175 \\
\hline \multicolumn{4}{|l|}{ Breakfast Habits } \\
\hline Rare & 5,35 & 0,01 & 0,004 \\
\hline Often & Reff & Reff & Reff \\
\hline \multicolumn{4}{|l|}{ Snack Types } \\
\hline Savory & 1,89 & 0,14 & 0,083 \\
\hline Sweet & Reff & Reff & Reff \\
\hline \multicolumn{4}{|l|}{ Fiber Consumption } \\
\hline $\operatorname{Rare}(<1-3 \mathrm{x} /$ week $)$ & 2,04 & 0,12 & 0,076 \\
\hline Often $(\geq 1 \mathrm{x} /$ day $)$ & Reff & Reff & Reff \\
\hline \multicolumn{4}{|l|}{ Types of Exercise } \\
\hline Dominant in Anaerobic & 3,31 & 27,4 & 0,074 \\
\hline Dominant in Aerobic & Reff & Reff & Reff \\
\hline \multicolumn{4}{|l|}{ Positive Family History } \\
\hline Yes & 1,14 & 0,02 & 0,001 \\
\hline No & Reff & Reff & Reff \\
\hline \multicolumn{4}{|c|}{ Fiberconsumption\#Breakfasthabit } \\
\hline Rare\#Often & 2,04 & 0,13 & 0,076 \\
\hline
\end{tabular}

Table 3 shows the final result of the causing factors of dysmenorrhea incidence as well as the Fit Model. There were 6 variables included into the Fit Model, including BMI, breakfast habits, types of snack, fiber consumption habits, types of exercise, dysmenorrhea history in family, and fiberconsumption\#breakfasthabit. The significant variables $(p$ value $\leq 0,05)$ were the breakfast habit and positive family history. The insignificant variables $(\mathrm{p}>0,05)$, including BMI, types of snack, fiber consumption habits, types of exercise, and fiberconsumption\#breakfasthabit, were confounding variables. The breakfast habit was the most dominant variable of the incidence of dysmenorrhea (B:5,35).

The result of analysis showed that the students rarely taking breakfast had 0,02 times higher of getting primary dysmenorrhea than the respondents who often took breakfast after controlled by other variables. The respondents who had positive family history (mother and sister) of primary dysmenorrhea gained odds 1,14 times higher of getting primary dysmenorrhea than those who did not have dysmenorrhea history in their family.

\section{Discussions}

Most of women experience pain during their menstrual period or known as dysmenorrhea or menstrual cramps. The pain is varied from mild to severe and could spread to stomach, back, posterior, and tight. It could also induce other complaints, such as headache, dizziness, nausea, diarrhea, constipation, and even fainting, thus dysmenorrhea becomes one of the main factors affecting the quality of life and social activity of women. ${ }^{6}$ According to the result of the study, there were two factors affecting dysmenorrhea on college students, including breakfast habit and positive family history of dysmenorrhea. 
Breakfast is the first food intake after a human stomach is unfilled during sleeping for 4-10 hours. Breakfast is an activity conducted from waking up in the morning to $09.00 \mathrm{a} . \mathrm{m}$. to fulfill about $15-30 \%$ of nutritional need in a day to create a healthy, active, and discerning life. Breakfast is the most important eating activity conducted in the morning before doing activities to fulfill the need of energy and nutrition in a day, including energy substances, building substances, and regulating substances. ${ }^{31}$ The result of this study shows that the majority of the female students who regularly took breakfast had a lower percentage $(52,6 \%)$ of experiencing primary dysmenorrhea than those who skipped breakfast. Female college students who rarely took breakfast gained 0,02 times higher risk of primary dysmenorrhea than those who often took breakfast (OR: 0,02 ; $\mathrm{p}: 0,004)$.

The research conducted by Eittah, Fathy A Hayam showed a difference in the incidence of primary dysmenorrhea between the group who had a daily breakfast habit and the group who had the habit of skipping breakfast frequently. ${ }^{32}$ The incidence of primary dysmenorrhea is more common in the group of young women who have the habit of skipping breakfast. This result is similar to Fujiwara $\mathrm{T}$ study in Japan which showed that there was a relationship between breakfast habits and the incidence of primary dysmenorrhea. Young women who have breakfast habits have lower pain levels than those who do not. Approximately, $71 \%$ of respondents who do not have early morning breakfast will experience a damage. This is related to the nutritional status that can cause a damage. Poor nutritional status increases the risk of primary dysmenorrhea, while a balanced diet and normal nutritional status can reduce the risk of primary dysmenorrhea. ${ }^{18}$

For young women, breakfast is a source of energy to carry out activities and learn at schools. However, there are still a lot of teenagers who skip breakfast that has effects on the blood iron deficiency, which causes anemia. Anemia had impacts on health problems and the quality of the teenager's life proven by the study that shows that there is a relationship between breakfast habit and the incident of anemia on teenagers. Teenagers who did not regularly take breakfast gained twice higher risk to get anemia than those who regularly took breakfast. ${ }^{6,33}$ A study states that the pain during menstrual period on young women who skip breakfast increases compared to young women who regularly take breakfast. Both malnutrition and over-nutrition could cause dysmenorrhea incidence. Meanwhile, a balance nutritional intake and a regular breakfast are suggested because they are highly ideal for a better metabolism and could decrease the risk of dysmenorrhea. ${ }^{18}$

A research conducted on female college students shows that the deficiency of iron due to skipping breakfast could cause iron deficiency anemia. ${ }^{34}$ It is supported by the research of Spence C in 2017 who states that a regular breakfast is known as an important healthy life style indicator and had a good effect on the physical and psychosocial wellbeing. Female adolescents who regularly take breakfast have higher carbohydrate, protein, and fiber intakes and lower fat intake 
than those who skip breakfast. A research argues that women with a quality breakfast gained a higher micro nutrients intake, while skipping breakfast could cause Vitamin A, Vitamin B6, Calcium, Zinc, Iron, Magnesium, and Copper deficiencies. ${ }^{18}$

The first aspect to be considered is how the failure of eating food in the beginning of the day could have a serious health consequence for female adolescents. According to a new evidence, we all need to consume for about $15-25 \%$ of our daily energy intake during breakfast (for about 300 500 calories for female and 375-625 calories for male). ${ }^{35}$ However, undoubtedly, there are a lot of culture variation of types of food for breakfast. The general advice from the health expert is to take a balance breakfast that provides energy slowly throughout morning. ${ }^{36}$ Skipping breakfast becomes the cause of the nutrition deficiency of adolescents. The nutrition deficiency becomes the most important factor that disturbs the hypothalamus-hypophysis-ovarium axis and contributes on the development of problems. ${ }^{18}$

Ten most favorite foods for breakfast in Indonesia include white rice, egg (sunny side up egg/omelets), fried tempeh, vegetable soup, fried fish, instant noodle, fried rice, sauteed vegetables, and fried tofu; while five most popular drinks for breakfast include water, sweet tea, condensed milk, and instant milk. ${ }^{31}$ Carbohydrate consumption, including consumption of bread and cereal, pasta, rice, white bread, biscuit, pastry, potato, and grains, is studied by Bajalan Z, Alimoradi Z \& Moafi, but there was no relationship reported between the consumption of these foods and dysmenorrhea. ${ }^{37}$ Moreover, related to the fruits and vegetables consumption, there was no association between the consumption of fruits and vegetables and dysmenorrhea. ${ }^{22}$ On the other hands, the calcium intake in food has a protection effect of dysmenorrhea. The calcium is absorbed in upper intestine and can maintain the ability of the muscle cells to respond the nerve stimulation through various functions, named stabilization. Therefore, milk consumption for breakfast can alleviate dysmenorrhea through the control of muscle nerves activity. Meanwhile, the decrease of calcium concentration can increase muscle spasm, spasticity, and muscle contraction. ${ }^{38}$ The example of food containing high calcium that can be used as the basic ingredients in breakfast menu include sardine, salmon, cheese, spinach, tofu, and red beans. Researchers had argued that school aged children, who missed breakfast, consumed less milk and endangered their whole diet quality. ${ }^{39}$

A good breakfast is containing $15-30 \%$ nutrients, which starts from waking up in the morning to 9 in the morning. The daily intake of breakfast for a young woman is 300-500 calories. The breakfast menu must have a balanced nutrition. This is useful for equipping the body to think and to do physical activity optimally after waking up in the morning. For students, breakfast has been proven to improve learning ability and stamina. ${ }^{35}$ An example of a breakfast menu design that can be used is by consuming: 1 serving of white rice or 2 scoops of rice (100 gr), 1 chicken egg (50gr), 1 medium tofu (40gr), and 1 glass of cow's milk (200 cc). 
Skipping breakfast is the cause of adolescent lack of nutrition. The insufficient nutrition affects the hormonal level changes due to the decrease of the energy level. ${ }^{2}$ Pain during menstrual period only occurs during ovulation. Prostaglandin plays a role in inducting uterus contraction, decreasing uterine bloodstream, and increasing hypersensitivity on peripheral nervous system that causes pain and cramps. The study of Chen Barret B and Kwekkeboom KL in 2016 found that ginger has been proven as the anti-inflammation agent and has therapeutic effect to relieve dysmenorrhea pain. These benefits come from gingerol and 6-shogaol as the active components of ginger. Gingerol works to prevent the formation of cyclooxygenase (COX) and the synthesis of prostaglandin. This mechanism is similar with the Non-steroidal anti-inflammatory drugs (NSAIDs) mechanism, such as ibuprofen and naproxen, that works to prevent the activity of COX. -1 and enzyme. ${ }^{36}$ Indonesia society has been consuming spices, such as ginger. ${ }^{36}$ Ginger is usually made as herbal drinks or food seasoning. Ginger has a warming effect; thus, it could decrease pain. Ginger water can be consumed after breakfast, at 10 o'clock, which is the time for morning tea or morning snack. ${ }^{40}$

There was a significant correlation between positive family history and dysmenorrhea in this research. It shows that genetic factors are involved in the primary dysmenorrhea pathogenesis. Therefore, positive family history can be a strong predictor of the dysmenorrhea incident on their offspring and siblings. In this research, $32,9 \%$ of respondents had positive family history, including mother or sibling who had a similar complaint, namely dysmenorrhea. College students who did not have primary dysmenorrhea history in their family and did not experience dysmenorrhea was $58,8 \%$. Where the result of the multivariate logistic regression analysis showed that the student who had a family member with primary dysmenorrhea complaint was 1,14 times higher to have primary dysmenorrhea risk than students who did not have positive family history (OR: 1,14 ; $p: 0,001)$.

Dysmenorrhea history in family is a predisposition factor of the occurrence of primary dysmenorrhea. ${ }^{41,42}$ Some researchers reported that a daughter from a mother who has menstrual complaint also experiences the inconvenience during menstruation, which is related to the habit learnt from the mother. ${ }^{43} \mathrm{~A}$ female child with dysmenorrhea history in family has three times higher chance of getting a similar complaint. ${ }^{41}$

Some previous research reported the similar relationship, showing genetic vulnerability from dysmenorrhea among women with genotype variant in some metabolic gene polymorphism. ${ }^{44} \mathrm{~A}$ research conducted by Ju H Jones M and Mishra G, Health A also studied genetic factor on the female monozygotic pairs and female dizygotic twins for menstruation. They report that menstrual symptoms are fully genetics. Genetics specially affects the menstrual pain and the menstrual cycle. However, another possible explanation is that the association can be related to the conditioned 
behavior learnt from mother or sister for the social appreciation or control for the pain, it could be because the same life habit and lifestyle in family. ${ }^{45}$

Some health problems caused by genetic factor can be inherited from mother to daughter. It is not necessary to blame the parents, all we can do is knowing the genetic history that we inherit. At least, we can anticipate the complaint, although it is impossible to avoid it. By knowing the risk factor in family, the emergence of the health problem risk can be minimized by carrying out a healthier lifestyle.

There are a lot of factors influencing the incidence of primary dysmenorrhea, thus this study has limitations. Research boundaries are used to avoid deviation or widening of the subject matter so that the research could be more focused and could facilitate discussion. Therefore, the research objectives will be achieved. Some of the limitations of this study include the wide coverage that only covers information on primary dysmenorrhea among female students in the FPOK UPI environment. The information presented is the relationship between BMI, type of exercise, dietary habits (breakfast habits, types of snack, fiber intake, ready-to-eat-food), and history of primary dysmenorrhea in family and the incidence of primary dysmenorrhea on the students. Data collection was only carried out through interviews without direct observation; thus, the authors were not able to confirm whether the participants gave honest answers about their types of exercise and eating habits.

\section{Conclusion}

By considering the negative effect of dysmenorrhea on the quality of life, an act should be taken to increase woman's knowledge about dysmenorrhea and to arrange a suitable lifestyle change, such as implementing a healthy life style by not skipping breakfast and designing healthy breakfasts menu. The promotion effort related to healthy breakfast habits should be conducted more intensively and continuously. Besides that, it is suggested that a healthy breakfast should fulfill at least $15-30 \%$ of Recommended Dietary Allowance.

\section{Acknowledgement}

The authors would like to deliver gratitude to the Institute of Research and Community Service of Universitas Pendidikan Indonesia for providing research grants and The Faculty of Sport and Health Education (FPOK) Universitas Pendidikan Indonesia that had helped the authors in conducting this research.

\section{Funding}

This research was funded by Institute of Research and Community Service of Universitas Pendidikan Indonesia. 


\section{Conflict of Interest}

No conflict of interest.

\section{Reference}

1. Dalal M, Saini P. An Exploratory Survey to Assess the Menstrual Characteristics and Prevalence of Dysmenorrhea in College Going Girls. Int J Sci Res. 2017;6(4):754-7.

2. Gibney MJ, Barr SI, Bellisle F, Drewnowski A, Fagt S, Livingstone B, Masset Gabriel, Moreiras V Gregorio, Moreno A Luis, Smith Jessica, Vieux Florent, Thieclecke Frank, Hopkins Sinead. Breakfast in human nutrition: The international breakfast research initiative. Nutrients. 2018;10(5):1-12.

3. Silviani YE, Karaman B, Septiana P. Pengaruh Teknik Relaksasi Nafas Terhadap Dismenorea. Hasanuddin J Midwifery. 2019;1(1):30.

4. Nurwana, Yusuf Sabilu AFF. Jurnal Dismenore Who. Jimkesmas J Ilm Mhs Kesehat Masy. 2018;2(6):1-14.

5. Bezuidenhout S, Mahlaba KJ, Nxumalo G, Meyer JC, Chukwu BO. Dysmenorrhoea: An overview. SA Pharm J. 2018;85(4):19-25.

6. Petraglia F, Bernardi M, Lazzeri L, Perelli F, Reis FM. Dysmenorrhea and related disorders. F1000Research. 2017;6:1-7.

7. Kazama M, Maruyama K, Nakamura K. Prevalence of dysmenorrhea and its correlating lifestyle factors in Japanese female junior high school students. Tohoku J Exp Med. 2015;236(2):107-13.

8. Pitangui ACR, Gomes MR de A, Lima AS, Schwingel PA, Albuquerque AP dos S, de Araújo RC. Menstruation Disturbances: Prevalence, Characteristics, and Effects on the Activities of Daily Living among Adolescent Girls from Brazil. J Pediatr Adolesc Gynecol. 2013;26(3):148-52.

9. Monday I, Anthony P, Olunu E, Otohinoyi D, Abiodun S, Owolabi A, Mobolaji B, Fakoya O J Adegbenro. Prevalence and correlation between diet and dysmenorrhea among high school and college students in saint vincent and grenadines. Open Access Maced J Med Sci. 2019;7(6):920-4.

10. Sholihah DM. the Correlation Between Exercise Activity, Genetic Background, Fast Food Consumption, and Dysmenorrhea. J Berk Epidemiol. 2019;7(2):129.

11. Buyuktuncer Z, Ayaz A, Dedebayraktar D, Inan-Eroglu E, Ellahi B, Besler HT. Promoting a Healthy Diet in Young Adults: The Role of Nutrition Labelling. Nutrients. 2018;10(10):112.

12. Moradpour R. The effects of regular aerobic exercise on primary dysmenorrhea in young girls. J Phys Act Horm. 2019;3(1):67-82. 
13. Kemenkes RI. Panduan Gizi Seimbang Pada Masa Covid-19.Pdf. Panduan Gizi Seimbang Pada Masa Pandemi COVID-19. Jakarta: Kementerian Kesehatan Republik Indonesia; 2020. p. 31.

14. Abadi Bavil D, Dolatian M, Mahmoodi Z, Akbarzadeh Baghban A. A comparison of physical activity and nutrition in young women with and without primary dysmenorrhea. F1000Research. 2018;7:59.

15. Matthewman G, Lee A, Kaur JG, Daley AJ. Physical activity for primary dysmenorrhea: a systematic review and meta-analysis of randomized controlled trials. Am J Obstet Gynecol. 2018;219(3):1-20.

16. Efrizal W. Persepsi Dan Pola Konsumsi Remaja Selama Pandemi Covid-19. Ekotonia J Penelit Biol Bot Zool dan Mikrobiol. 2020;05(2):43-8.

17. Barcikowska Z, Rajkowska-Labon E, Grzybowska ME, Hansdorfer-Korzon R, Zorena K. Inflammatory markers in dysmenorrhea and therapeutic options. Int J Environ Res Public Health. 2020;17(4):1-14.

18. Fujiwara T, Ono M, Iizuka T, Sekizuka-Kagami N, Maida Y, Adachi Y, Fujiwara H, Yoshikawa $\mathrm{H}$. Breakfast skipping in female college students is a potential and preventable predictor of gynecologic disorders at health service centers. Diagnostics. 2020;10(7):1-11.

19. Tavallaee M, Joffres MR, Corber SJ, Bayanzadeh M, Rad MM. The prevalence of menstrual pain and associated risk factors among Iranian women. J Obstet Gynaecol Res. 2011;37(5):442-51.

20. Mohamadirizi S, Kordi M. The relationship between food frequency and menstrual distress in high school females. Iran J Nurs Midwifery Res. 2015;20(6):689.

21. Grandi G, Ferrari S, Xholli A, Cannoletta M, Palma F, Romani C, Volpe A, Cagnacci A. Prevalence of menstrual pain in young women: What is dysmenorrhea? J Pain Res. 2012;5:169-74.

22. Abu Helwa HA, Mitaeb AA, Al-Hamshri S, Sweileh WM. Prevalence of dysmenorrhea and predictors of its pain intensity among Palestinian female university students. BMC Womens Health. 2018;18(1):1-11.

23. Arianto NT. Pola Makan Mi Instan: Studi Antropologi Gizi Pada Mahasiswa Antropologi Fisip Unair. 2013;II(1):27-40.

24. El Ansari W, Stock C, Mikolajczyk RT. Relationships between food consumption and living arrangements among university students in four European countries - A crosssectional study. Nutr J. 2012;11(1):1-7.

25. Sundari N, Sari DNA, Timiyatun E, Kusumasari V. Dietary Habit is Associated With Dysmenorrhea Among Adolescent. Str J Ilm Kesehat. 2020;9(2):1359-69.

26. Fitria L, Ifdil I. Kecemasan Remaja Pada Masa Pandemi Covid -19. J Educ J Pendidik 
Indones. 2020;6(1):1.

27. Kurniawati NWW, Suarya LMKS. Gambaran kecemasan remaja perempuan dengan berat badan berlebih. J Psikol Udayana. 2019;6(02):280.

28. Swaffield JB, Guo Q. Environmental Stress Effects On Appetite: Changing Desire For High- And Low-Energy Foods Depends On The Nature Of The Perceived Threat. Evol Mind Behav. 2020;18(1):1-13.

29. Surur AZ, Putri M, Multazam AF. Body Mass Index and Dysmenorrhea in Female Teenagers. Indones Contemp Nurs J (ICON Journal). 2019;4(1):21.

30. Abreu-Sánchez A, Parra-Fernández ML, Onieva-Zafra MD, Fernández-Martínez E. Perception Of Menstrual Normality And Abnormality In Spanish Female Nursing Students. Int J Environ Res Public Health. 2020;17(17):1-12.

31. Hardinsyah H, Aries M. Jenis Pangan Sarapan Dan Perannya Dalam Asupan Gizi Harian Anak Usia 6-12 Tahun Di Indonesia. J Gizi dan Pangan. 2016;7(2):89.

32. Eittah HFA. Effect Of Breakfast Skipping On Young Females' Menstruation. Heal Sci J. 2014;8(4):469-84.

33. Ekasanti I, Adi AC, Yono M, Nirmala G F, Isfandiari MA. Determinants of Anemia among Early Adolescent Girls in Kendari City. Amerta Nutr. 2020;4(4):271.

34. Shill KB, Karmakar P, Kibria MG, Das A, Rahman MA, Hossain MS, Sattar MM. Prevalence Of Iron-Deficiency Anaemia Among University Students in Noakhali Region, Bangladesh. J Heal Popul Nutr. 2014;32(1):103-10.

35. Spence C. Breakfast: The Most Important Meal Of The Day? Int J Gastron Food Sci. 2017;8:1-6.

36. Chen CX, Barrett B, Kwekkeboom KL. Efficacy of Oral Ginger (Zingiber officinale) for Dysmenorrhea: A Systematic Review and Meta-Analysis. Evidence-based Complement Altern Med. 2016;2016:1-9.

37. Bajalan Z, Alimoradi Z, Moafi F. Nutrition As A Potential Factor Of Primary Dysmenorrhea: A Systematic Review Of Observational Studies. Gynecol Obstet Invest. 2019;84(3):209-24.

38. Moghaddam Tabrizi F, Barjasteh S, Rezaei E. Lifestyle Factors Related to Dysmenorrhea Among High School Students. J Client-centered Nurs Care. 2018;4(1):53-9.

39. Cormick G, Belizán JM. Calcium Intake And Health. Nutrients. 2019;11(7):1-16.

40. Xu Y, Yang Q, Wang X. Efficacy of herbal medicine (cinnamon/fennel/ginger) for primary dysmenorrhea: a systematic review and meta-analysis of randomized controlled trials. J Int Med Res. 2020;48(6):1-12.

41. Joshi T, Patil A, Kural M, Noor N, Pandit D. Menstrual characteristics and prevalence of dysmenorrhea in college going girls. J Fam Med Prim Care. 2015;4(3):426. 
42. Sharlin P, Sukandar H, Fadil R. Familial Predisposition of Primary Dysmenorrhea among Senior High School Girl Students. Althea Med J. 2015;2(4):579-83.

43. Guthold R, Stevens GA, Riley LM, Bull FC. Global Trends In Insufficient Physical Activity Among Adolescents: A Pooled Analysis Of 298 Population-Based Surveys With 1.6 Million Participants. Lancet Child Adolesc Heal. 2020;4(1):23-35.

44. Jones A V., Hockley JRF, Hyde C, Gorman D, Sredic-Rhodes A, Bilsland J, Gordon M, Furlotte AN, Hu Youna, Hinds AD, Cox JP, Scollen S. Genome-Wide Association Analysis Of Pain Severity In Dysmenorrhea Identifies Association At Chromosome, Near The Nerve Growth Factor Locus. Pain. 2016;157(11):2571-81.

45. Ju H, Jones M, Mishra G. The prevalence and risk factors of dysmenorrhea. Epidemiol Rev. 2014;36(1):104-13. 